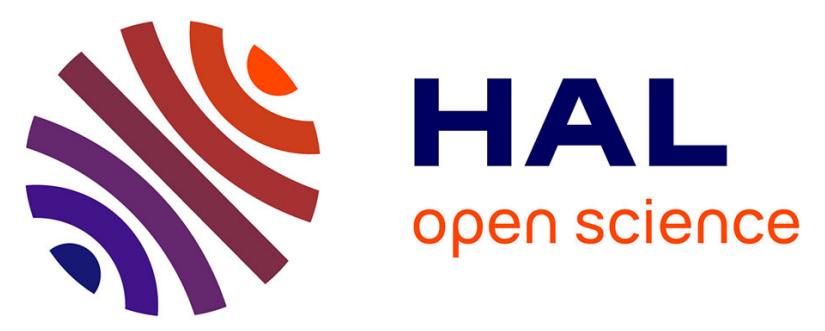

\title{
KSHV DNA viraemia correlates with low CD4+ cell counts in Italian males at the time of diagnosis of HIV infection
}

Saverio Giuseppe Parisi, Caterina Boldrin, Samantha Andreis, Roberto

Ferretto, Rodolfo Fuser, Marina Malena, Vinicio Manfrin, Sandro Panese,

Renzo Scaggiante, Luca Dori, et al.

\section{To cite this version:}

Saverio Giuseppe Parisi, Caterina Boldrin, Samantha Andreis, Roberto Ferretto, Rodolfo Fuser, et al.. KSHV DNA viraemia correlates with low CD4+ cell counts in Italian males at the time of diagnosis of HIV infection. Journal of Medical Virology, 2011, 83 (3), pp.384. 10.1002/jmv.21987 . hal-00613772

\section{HAL Id: hal-00613772 \\ https://hal.science/hal-00613772}

Submitted on 6 Aug 2011

HAL is a multi-disciplinary open access archive for the deposit and dissemination of scientific research documents, whether they are published or not. The documents may come from teaching and research institutions in France or abroad, or from public or private research centers.
L'archive ouverte pluridisciplinaire HAL, est destinée au dépôt et à la diffusion de documents scientifiques de niveau recherche, publiés ou non, émanant des établissements d'enseignement et de recherche français ou étrangers, des laboratoires publics ou privés. 


\section{Journal of Medical Virology}

WILEY

\section{KSHV DNA viraemia correlates with low CD4+ cell counts in Italian males at the time of diagnosis of HIV infection}

\begin{tabular}{|c|c|}
\hline Journal: & Journal of Medical Virology \\
\hline Manuscript ID: & JMV-10-1763.R2 \\
\hline Wiley - Manuscript type: & Research Article \\
\hline $\begin{array}{r}\text { Date Submitted by the } \\
\text { Author: }\end{array}$ & 27-Sep-2010 \\
\hline Complete List of Authors: & $\begin{array}{l}\text { Parisi, Saverio; Padova University, Department of Histology, } \\
\text { Microbiology and Medical Biotechnology } \\
\text { Boldrin, Caterina; Padova University, Department of Histology, } \\
\text { Microbiology and Medical Biotechnology } \\
\text { Andreis, Samantha; Padova University, Department of Histology, } \\
\text { Microbiology and Medical Biotechnology } \\
\text { Ferretto, Roberto; Schio Hospital, Infectious Diseases Unit } \\
\text { Fuser, Rodolfo; Treviso Hospital, Infectious Diseases Unit } \\
\text { Malena, Marina; ULSS } 20 \text { Verona, Center of Preventive Medicine } \\
\text { Manfrin, Vinicio; Vicenza Hospital, Infectious Diseases Unit } \\
\text { Panese, Sandro; Venezia Hospital, Infectious Diseases Unit } \\
\text { Scaggiante, Renzo; Padova Hospital, Infectious Diseases Unit } \\
\text { Dori, Luca; Clinica Infectious Disease, Dept. Pubblic Health, Tor } \\
\text { Vergata University } \\
\text { Sarmati, Loredana; Clinica Infectious Disease, Dept. Pubblic Health, } \\
\text { Tor Vergata University } \\
\text { Biasolo, Maria Angela; Padova University, Department of Histology, } \\
\text { Microbiology and Medical Biotechnology } \\
\text { Nicastri, Emanuele; Istituto Nazionale di Malattie Infettive Lazzaro } \\
\text { Spallanzani, Infectious Diseases Unit } \\
\text { Andreoni, Massimo; Tor Vergata University, Infectious Diseases } \\
\text { Department } \\
\text { Cruciani, Mario; ULSS } 20 \text { Verona, Center of Preventive Medicine } \\
\text { Palü, Giorgio; University of Padova, Department of Histology, } \\
\text { Microbiology and Medical Biotechnologies }\end{array}$ \\
\hline Keywords: & KSHV-DNA, HIV, immunodeficiency, homosexual relationship \\
\hline
\end{tabular}

\section{SCHOLARONE" Manuscripts}




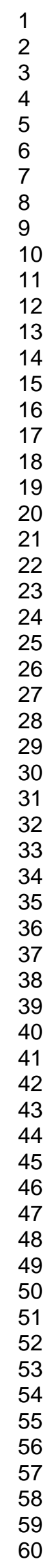

John Wiley \& Sons 
1 Table 1. Demographic, virological, and immunological characteristics of untreated HIV-

2 seropositive patients according to the presence of KSHV DNA in PBMCs.

3

\begin{tabular}{|c|c|c|c|c|}
\hline & $\begin{array}{l}\text { All patients } \\
\quad(n=481)\end{array}$ & $\begin{array}{c}\text { KSHV neg } \\
(n=407)\end{array}$ & $\begin{array}{c}\text { KSHV pos } \\
(n=74)\end{array}$ & $p$ value \\
\hline Mean age in years $( \pm S D)$ & $40.3( \pm 11.2)$ & $41.7( \pm 11.7)$ & $40.0( \pm 11.1)$ & 0.26 \\
\hline Risk factor for HIV infection: & & & & \\
\hline *unprotected homosexual relationship, (\%) & $282(64.4)$ & $226(61.4)$ & $56(80.0)$ & 0.003 \\
\hline Patients with primary HIV infection, n. (\%) & $102(21.2)$ & $92(22.6)$ & $10(13.7)$ & 0.09 \\
\hline$* *$ Patients with B subtype (\%) & $401(88.5)$ & $339(88.1)$ & $62(91.2)$ & 0.45 \\
\hline Mean CD4+ cell count $/ \mu \mathrm{l}( \pm \mathrm{SD})$ & $449( \pm 288)$ & $461( \pm 291)$ & $389( \pm 264)$ & 0.06 \\
\hline Patient CD4+ cell count, n (\%) & & & & 0.08 \\
\hline$<200$ cells & $87(18.1)$ & $70(17.2)$ & $18(24.3)$ & \\
\hline $200-350$ cells & $112(23.3)$ & $89(21.9)$ & $22(29.7)$ & \\
\hline$>350$ cells & $282(58.6)$ & $248(60.9)$ & $34(46.0)$ & 0.025 \\
\hline Percentage of CD4+ cells $( \pm \mathrm{SD})$ & $22.1( \pm 10.6)$ & $22.3( \pm 10.5)$ & $21.2( \pm 10.6)$ & 0.44 \\
\hline HIV RNA cp/ml ( \pm SD) & $\begin{array}{c}268061 \\
( \pm 872183)\end{array}$ & $\begin{array}{c}280623 \\
( \pm 940158)\end{array}$ & $\begin{array}{c}200150 \\
( \pm 304285)\end{array}$ & 0.50 \\
\hline HIV DNA cp x $10^{6}$ PBMCs $( \pm$ SD) & $2893( \pm 4429)$ & $2799( \pm 4483)$ & $3340( \pm 4162)$ & 0.38 \\
\hline
\end{tabular}

$4 * \%$ of 438 evaluable patients

$5 * * \%$ of 453 evaluable data

6 


\section{$1 \quad$ Table 2}

2 Univariate analysis of 60 untreated HIV-seropositive patients with KSHV DNA

3 in PBMCs and for whom plasma samples were available/analysed 4

\begin{tabular}{|c|c|c|c|c|}
\hline & $\begin{array}{l}\text { All patients } \\
\qquad(n=60)\end{array}$ & $\begin{array}{c}\text { KSHV pl pos } \\
\quad(n=33)\end{array}$ & $\begin{array}{l}\text { KSHV pl neg } \\
\quad(n=27)\end{array}$ & $\begin{array}{c}P \\
\text { value }\end{array}$ \\
\hline Mean age in years $( \pm \mathrm{SD})$ & $42.1( \pm 11.5)$ & $44.1( \pm 12.8)$ & $39.2( \pm 8.8)$ & 0.10 \\
\hline $\begin{array}{l}\text { Risk factor for HIV infection: } \\
\text { unprotected homosexual relationship (\%) }\end{array}$ & $47(78)$ & $29(87.9)$ & $18(66.6)$ & 0.37 \\
\hline Patients with primary HIV infection, n. (\%) & $7(11.6)$ & $5(15.1)$ & $2(7.4)$ & 0.46 \\
\hline Patients with B subtype (\%) & $55(91.6)$ & $29(87.8)$ & $26(96.3)$ & 0.27 \\
\hline CD4+ cell count $/ \mu \mathrm{l}( \pm \mathrm{SD})$ & $404( \pm 267)$ & $325( \pm 258)$ & $513( \pm 244)$ & 0.006 \\
\hline Patient CD4+ cell count, n. (\%) & & & $\Omega(\Omega)$ & 0.002 \\
\hline$<200$ cells & $13(21.7)$ & & & \\
\hline 200-350 cells & $19(31.7)$ & $9(27.2)$ & $10(37.0)$ & \\
\hline$>350$ cells & $28(46.6)$ & $11(33.3)$ & $17(63.0)$ & 0.01 \\
\hline Percentage of CD4+ cells $( \pm$ SD) & $22.1( \pm 10.4)$ & $19.2( \pm 11.4)$ & $25.8( \pm 7.7)$ & 0.019 \\
\hline HIV RNA cp/ml ( \pm SD) & $\begin{array}{r}197691 \\
( \pm 311073)\end{array}$ & $\begin{array}{r}224658 \\
(+313325)\end{array}$ & $\begin{array}{r}162095 \\
( \pm 310812)\end{array}$ & 0.45 \\
\hline HIV DNA cp x $10^{6}$ PBMCs $( \pm$ SD) & $3446( \pm 4362)$ & $3252( \pm 3786)$ & $3786( \pm 5407)$ & 0.67 \\
\hline
\end{tabular}


1 Table 3 Multivariate analysis of untreated HIV-seropositive patients with KSHV DNA in

2 PBMCs according to the presence of KSHV DNA in plasma

3

4

\begin{tabular}{|l|l|l|l|}
\hline & $\mathrm{p}$ & OR & $95 \%$ CI \\
\hline Patients with age $>$ median age & 0.70 & 0.06 & $-0.24-0.35$ \\
\hline $\begin{array}{l}\text { Risk factor for HIV infection } \\
\text { unprotected homosexual relationship }\end{array}$ & 0.55 & 0.09 & $-0.22-0.40$ \\
\hline CD4+ cell count/ml & 0.03 & 0.001 & $<0.001-0.001$ \\
\hline Patients with $>$ median HIV RNA cp & 0.28 & -0.17 & $-0.48-0.14$ \\
\hline
\end{tabular}


KSHV DNA viraemia correlates with low CD4+ cell count in Italian males

Saverio G. Parisi ${ }^{\mathrm{a} *}$, Caterina Boldrin ${ }^{\mathrm{a}}$, Samantha Andreis ${ }^{\mathrm{a}}$, Roberto Ferretto ${ }^{\mathrm{b}}$, Rodolfo Fuser ${ }^{\mathrm{c}}$,

Marina Malena ${ }^{\mathrm{d}}$, Vinicio Manfrin ${ }^{\mathrm{e}}$, Sandro Panese ${ }^{\mathrm{f}}$, Renzo Scaggiante ${ }^{\mathrm{g}}$, Luca Dori ${ }^{\mathrm{h}}$, Loredana

Sarmati $^{\mathrm{h}}$, Maria A. Biasolo ${ }^{\mathrm{a}}$, Emanuele Nicastri ${ }^{\mathrm{i}}$, Massimo Andreoni ${ }^{\mathrm{h}}$, Mario Cruciani ${ }^{\mathrm{d}}$,

$7 \quad$ Giorgio Palù ${ }^{\mathrm{a}}$

8

$11{ }^{\mathrm{b}}$ Infectious Disease Unit, City Hospital, via De Lellis, 36015 Schio

$12{ }^{\mathrm{c}}$ Infectious Disease Unit, City Hospital, piazza Ospedale 1, 31100 Treviso

13 Center of Preventive Medicine, ULSS 20, via Germania 20, 37135 Verona,

$14{ }^{\mathrm{e}}$ Infectious Disease Unit, San Bortolo Hospital, via Rodolfi 37, 36100 Vicenza

${ }^{\mathrm{f}}$ Infectious Disease Unit, City Hospital, via Paccagnella 11, 30170 Mestre-Venezia

$16{ }^{\mathrm{g}}$ Infectious Disease Unit, Padova Hospital, via Ospedale 1, 35100 Padova

$17{ }^{\mathrm{h}}$ Infectious Disease Unit, Tor Vergata University, V. Montpellier 1, 00133, Roma.

18 istituto Nazionale di Malattie Infettive Lazzaro Spallanzani, via Portuense 292, 00149 Roma

*Corresponding Author: Parisi Saverio Giuseppe, MD.

21 Department of Histology, Microbiology and Medical Biotechnology, Via Gabelli 63, 35100

22 Padova, Italy. tel +390498272344, fax +390498272355, e-mail: $\underline{\text { saverio.parisi@ unipd.it }}$

23 Short title: KSHV viraemia in patients infected with HIV 


\section{Abstract}

3 To evaluate the relevance, virological and immunological markers of Kaposi sarcoma

4 herpesvirus 8 (KSHV) viraemia in Italian male patients at the time of diagnosis of infection 5 with HIV-1, 481 men infected with HIV were recruited consecutively. The presence of KSHV 6 DNA was evaluated in peripheral blood mononuclear cells (PBMCs) and in plasma and 7 correlated with demographic and viro-immunological parameters.

8 Seventy-four patients had KSHV DNA detected in PBMCs. By univariate analysis, the 9 presence of KSHV DNA was associated significantly with unprotected homosexual 10 relationships $(p=0.003)$ and it was significantly higher in patients with $C D 4+$ cell $<350$ 11 ( $\mathrm{p}=0.025)$. By multivariate analysis, homosexual relationships were associated independently 12 with KSHVDNA in PBMCs (OR: 3.25; 95\% CI: 1.1-9.7; $\mathrm{p}=0.035$ ). Among the 74 patients 13 with KSHVDNA detected in PBMCs, plasma samples from 60 were analysed and 33 were 14 positive for KSHV DNA. The CD4+ cell counts and percentages were significantly lower in 15 patients with KSHV DNA in both PBMCs and plasma as compared to patients with only 16 KSHV DNA in PBMCs ( $\mathrm{p}=0.006$ and $\mathrm{p}=0.019$, respectively). Among the patients with KSHV 17 DNA detected in PBMCs, all 13 patients with CD4+ cells count $<200$ had detectable levels of $18 \mathrm{KSHV}$ in their plasma. By multivariate analysis adjusted for the epidemiologic and 19 virological parameters, low CD4+ cell count was the only independent variable associated 20 with the presence of KSHV DNA in plasma (OR, 0.001; 95\% CI, <0.001-0.001; p=0.03).

21 In HIV-positive antiretroviral therapy-naïve males, KSHV active replication as detected by 22 KSHV DNA in plasma was associated significantly with low CD4+ cell count.

Key words: KSHV DNA, HIV, immunodeficiency, homosexual relationship. 


\section{Introduction}

2

3 Kaposi's Sarcoma-associated herpesvirus (KSHV) is linked causally to primary effusion

4 lymphoma, multicentric Castleman disease, and all epidemiological forms of Kaposi's 5 sarcoma (KS) (Boshoff and Weiss, 1998). The prevalence of KSHV varies between countries

6 and populations. Variable routes of transmission, both sexual and non-sexual, have been 7 described (Schulz \& Moore, 1999; Hengge et al., 2002). In areas with low seroprevalence, 8 KSHV appears to be acquired predominantly through sexual contact, and sex between men 9 may be an important route of transmission (Schulz \& Moore, 1999). Familial clustering of $10 \mathrm{KSHV}$ is observed frequently in endemic regions, where nasal secretions and saliva may be 11 the sources of KSHV transmission (Plancoulaine et al., 2002; Andreoni et al., 1999; Rezza et 12 al., 2000).

13 Variable seroprevalence of KSHV has been reported among subjects infected with HIV 14 (Campbell et al., 1999; Laney et al., 2004)). In Italy, its overall prevalence in HIVseropositive people in $1997-98$ was demonstrated to be $31.4 \%$, an increase from the $1987-88$ prevalence of $14.6 \%$, suggesting a spread of infection among HIV-seropositive subjects, and 17 possibly from them to the HIV-negative community, by sexual and non-sexual routes (Parisi SG, Sarmati L et al., 2002).

19 HIV and KSHV are able to influence each other, and there is in vitro evidence that suggest 20 the ability of one virus to facilitate the replication of the other. HIV activates lytic cycle 21 replication of KSHV, and KSHV lytic antigens interact with HIV Tat to increase the cell's 22 susceptibility to HIV infection (Zeng et al., 2007; Varthakavi et al., 2002). In vivo, HIV-1 23 infection has been associated with the presence of KSHV in any mucosal surface, and the 24 presence of KSHV DNA in PBMCs is predictive of the development of KS in patients 25 infected with HIV (Moore et al., 1996; Taylor et al., 2004, Engels et al., 2003). KSHV-DNA was more detected frequently in people infected with HIV and in the oropharynx and 
1 peripheral blood of Ugandans with endemic and epidemic KS (Johnston et al., 2009). KSHV

2 DNA is detectable in KS tissues (Chang et al., 1994), in PBMCs from patients with KS and

3 multicentric Castleman disease, and in PBMCs and effusion fluid samples from patients with

4 primary effusion lymphoma (Marcelin et al., 2007). Among KS patients, KSHV DNA has

5 been detected in both plasma and PBMCs, and often no consistent difference between

6 biological compartments is detected (Lin et al 2009). KSHV-infected cells were detected at a

7 very low frequency in the inguinal lymph nodes of HIV-1-seropositive subjects without

8 KSHV-associated diseases (Campbell et al., 2005), suggesting that the latent infection of

9 lymph node cells provides a mechanism for the persistence of KSHV in KSHV/HIV-1-co10 infected people.

11 Although effective HIV suppression has been correlated with the regression of KS after 12 antiretroviral therapy (Martinez et al., 2006), the persistence of KS despite seemingly 13 effective antiretroviral therapy (e.g., an undetectable HIV load) is not rare (Krown et al., 14 2008). However, the interactions between immune responses, KSHV replication, and their 15 relative contribution to KS have not been well characterised to date.

16 The aim of the study was to evaluate the prevalence of KSHV DNA viraemia in male patients 17 from northeastern Italy with chronic and acute HIV-1 infections at the time of HIV diagnosis. 18 Moreover, correlations between KSHV viraemia and the virological and immunological 19 parameters of HIV infection were evaluated. 


\section{Materials and Methods}

2

3 Study population

4 Four hundred and eighty one men infected with HIV-1 were enrolled at six Infectious

5 Diseases Units located in Veneto, Italy. The patients were recruited consecutively from July

61,2004 to December 31, 2008 after obtaining their written informed consent to participate in

7 the study. The ethics committee of the hospitals gave approval for the study.

8 The eligibility criteria included being of Italian origin, $>18$ years of age, and having

9 antiretroviral-drug-naïve status.

10 Blood samples were submitted to the Laboratory of Virology at the University of Padua,

11 stored within 6 hours from collection, and analysed subsequently.

12 A primary or recent HIV infection was defined by the presence of either of the following: (i) a 13 negative or indeterminate HIV antibody-ELISA associated with HIV RNA-positive plasma; 14 or (ii) an initially negative test for HIV antibodies followed by positive serology within 18 15 months.

16 The HIV RNA plasma viral load assessment (using Roche Cobas AmpliPrep-Cobas TaqMan 17 HIV-1, version 1 assay, F. Hoffmann-La Roche, Diagnostics Division, Basel, Switzerland) and HIV genotypic analysis to detect subtype were performed as described previously (Parisi 19 et al., 2007).

20 CD4+ cell counts and percentages were determined at enrolment. Blood collected in EDTA 21 was separated into plasma and cells by Ficoll-Paque Plus density gradient centrifugation. 22 Aliquots of plasma and dry pellets of $2 \times 10^{6} \mathrm{PBMCs}$ were stored at $-80^{\circ} \mathrm{C}$ until use.

\section{$23 \underline{\text { KSHV DNA analysis }}$}

24 The extraction and purification of DNA from cells and plasma samples was performed using 25 the QIAmp Blood kit (Qiagen, Inc., Chatsworth, CA). KSHV DNA from cell and plasma samples was detected using a real-time polymerase chain reaction (RT-PCR; with TaqMan 
1 probe, Applied Biosystems, Foster City, CA) of open reading frame 26 (ORF26), as described

2 previously (White and Campbell, 2000). The nucleotide sequence targeted by the primers and

3 probes is conserved highly among the three major subgroups of KSHV (Poole et al., 1999).

4 During all DNA extractions and purifications, precautions were taken to reduce the risk of

5 false-positive results.

6 Cellular HIV DNA quantitation

7 The Real-Time TaqMan protocol published by Viard and colleagues (Viard et al., 2004) was

8 used to quantify the HIV DNA copy number in PBMCs. The cell line 8E5, containing one

9 copy of integrated HIV DNA in each cell, was used to build a standard curve. The sensitivity

10 of the test was 13.3 copies $/ 10^{6}$ PBMCs.

\section{Statistical analysis}

12 The variables initially taken into account were age, risk factors for HIV infection (men who

13 had sex with a man vs. other risk groups), primary HIV infection, HIV subtype (B subtype vs.

14 other subtypes), CD4+ cell count, HIV RNA, and HIV DNA load. Among these, age was a 15 quantitative variable, while primary HIV infection, HIV subtype, and the presence of drug 16 resistance mutations were binary (yes/no) variables and were coded as 1/0. CD4+ cell count, 17 HIV RNA, and HIV DNA were both quantitative and discrete variables.

18 Univariate analyses were performed using all of the covariates, taking them both (when 19 appropriate) as continuous variables, as well as categorising by clinically relevant values. Chi 20 square and Kruskal-Wallis tests were used to assess differences between patient groups with 21 reference to categorical and continuous variables, respectively. The significance level was set 22 at 0.05 and all $P$ values were two-tailed. To obtain an adjusted analysis while accounting for 23 all possible risk factors, a multiple logistic regression model was used. Age, HIV-RNA level, 24 and all of the significant variables in the univariate analysis were included in the multivariable 25 model. 
1 All of the analyses were performed on an intention-to-treat basis using SPSS for Windows

213.0 (SPSS Inc, Chicago, Illinois).

3

4

5

6

7

8

9

10

11

12

13

14

15

16

17

18

19

20

21

22

23

24

25

26

John Wiley \& Sons 
Results

2

3 Of the 481 patients enrolled, in 43 cases (8.9\%) it was not possible to define their risk for HIV

4 infection. Of the remaining 438 patients, 282 were homosexual, 90 were heterosexual and 66

5 were intravenous drug abusers. Additionally, 102 patients had a primary HIV infection and 6379 patients had a chronic infection.

7 Patients with chronic HIV infections were older $(41 \pm 11.4$ vs. $37.6 \pm 10.2$ years, $p=0.008)$ and 8 had CD4+ cell counts $(413.8 \pm 273.4$ vs. $603.9 \pm 297.5$ cells/ $\mu 1, \mathrm{p}<0.001)$ and percentages $9 \quad(21.2 \pm 10.2$ vs. $26.6 \pm 10.5 \%, \mathrm{p}<0.001)$ significantly lower than the patients with primary 10 infections.

11 Table 1 presents the population of patients infected with HIV studied according to the 12 presence of KSHV DNA in PBMCs and different epidemiological and viro-immunological 13 parameters.

14 Of the 481 enrolled patients, 74 (15.4\%) had KSHV DNA detected in their PBMCs. By 15 univariate analysis, unprotected homosexual relationships and a CD4+ cell count $<350$ 16 cells/ $\mu \mathrm{l}$ were associated significantly with the presence of KSHV DNA in PBMCs ( $\mathrm{p}=0.003$ 17 and $\mathrm{p}=0.025$, respectively).

18 Patients with primary HIV infections had a lower (but not significantly lower) rate of KSHV 19 DNA positivity in PBMCs in comparison to patients with chronic infections. No significant 20 differences in HIV RNA or HIV DNA levels were found between KSHV DNA-positive and 21 KSHV DNA-negative patients.

22 By multivariate analysis adjusted for different epidemiological and virological parameters, 23 having a homosexual relationship (OR: 3.25; 95\% CI: 1.1-9.7; $\mathrm{p}=0.035$ ) was the only 24 parameter that was associated independently with the presence of KSHV DNA in PBMCs. 
1 Table 2 presents the univariate analysis of the population of HIV/KSHV co-infected male

2 patients studied in relation to the simultaneous presence of KSHV DNA in PBMCs and

3 plasma.

4 Among the 74 subjects with KSHV DNA detected in PBMCs, the presence of KSHV DNA in 5 plasma was analysed for 65 subjects from whom plasma specimens were available. Of the 65 6 patients, $38(58.4 \%)$ also had KSHV DNA-positive plasma. Overall, five patients had an 7 ultimate diagnosis of KS and were excluded from the evaluation. Among the 60 non-KS 8 patients, $33(55 \%)$ had KSHV DNA detected in both PBMCs and plasma; $28(85 \%)$ of these 9 patients had a chronic HIV infection and 5 had a primary HIV infection. The CD4+ cell 10 counts and percentages were significantly lower in patients with detectable levels of KSHV 11 DNA in both PBMCs and plasma compared to patients with KSHV DNA detectable only in 12 PBMCs $(\mathrm{p}=0.006$ and $\mathrm{p}=0.019$, respectively). Moreover, among patients with KSHV DNA 13 detected in PBMCs, all 13 subjects with CD4+ cell counts <200 cells/ $\mu 1$ also had KSHV DNA 14 detectable in plasma.

15 In the multivariate analysis (Table 3) adjusted for the different epidemiologic and virological 16 parameters, CD4+ cell count was the only independent variable associated with the presence 17 of KSHV DNA in the plasma of co-infected HIV/KSHV patients (OR, 0.001; 95\% CI, $18<0.001-0.001 ; \mathrm{p}=0.03)$.

19 A subgroup of 20 patients with KSHV DNA detected in PBMCs and plasma were re-analysed 20 for the presence of KSHV DNA in PBMCs and plasma in a follow-up study.

21 Nine subjects still had KSHV DNA detectable in PBMCs and plasma after a mean time of 19 months. Six of these subjects were still highly active antiretroviral therapy (HAART)-naïve and three were on HAART, two of whom were HIV plasma viraemic at the time of the second 24 analysis. Of the 14 patients who were successfully HAART-treated $(<50$ HIV RNA 25 copies/ml), 11 were KSHV DNA-negative in PBMCs and plasma after a mean time of 17 26 months. 
1 Moreover, among the 14 patients treated with HAART, the 11 patients who were negative for

2 KSHV DNA had a mean increase in their CD4+ cell counts of 249 cells/ $\mu 1$ (range 57-603),

3 whereas the 3 treated patients with detectable levels of KSHV DNA had CD4+ cell count 4 increases of 57,97 , and 74 cells/ $\mu 1$. 


\section{Discussion}

2

3 The presence of KSHV DNA in a cohort of patients at the time of their initial diagnosis of

4 HIV infection was studied. Out of the 481 evaluated subjects, $74(15.3 \%)$ were found to have 5 detectable levels of KSHV DNA in their PBMCs. Approximately half of the subjects found to 6 be PBMC-positive had concomitant active KSHV replication in their plasma.

7 The presence of KSHV DNA in PBMCs is predictive of the development of KS in HIV8 infected patients, and KSHV DNA has been detected in up to $70 \%$ of HIV-related KS cases 9 (Whitby et a., 1995; Moore et al., 1996). Previous studies have reported variable results on the 10 prevalence of KSHV DNA in HIV-1-infected people without KS. Laney and colleagues found 11 KSHV DNA in the PBMCs of $28.9 \%$ of patients without KS, a rate almost double that of the 12 cohort in this study (Laney et al., 2004). By contrast, Campbell et al (1999) found that $18 \%$ of 13 KSHV/HIV-1 co-infected people without KS have detectable KSHV DNA in their PBMCs. 14 The lower prevalence in the cohort of this study may be due to the distribution of risk factors 15 for HIV, with only $67 \%$ of our subjects being homosexual compared to $>90 \%$ in the previous 16 studies. The median CD4+ cell values were lower in the studies by Campbell and by Laney 17 than they were in the cohort of this study.

18 In this study, patients with detectable KSHV DNA had lower CD4+ cells count compared to 19 patients without detectable KSHV DNA. Using multivariate analysis, CD4+ cell count was 20 found to be correlated negatively with active KSHV replication. By contrast, any correlation 21 between KSHV DNA detection and either HIV RNA, HIV DNA viral load, or HIV subtype 22 was not found. The lack of a correlation between the presence of KSHV DNA and HIV 23 viraemia seems to confirm previous observations that assign a greater role to the immune 24 response (in particular the NK-type response) and CD4+ cell recovery rather than to HIV 25 replication in the control of KS in AIDS patients (Sirianni et al., 2002; Cattelan et al., 2001). 
1 subjects with chronic HIV infections than in those with acute infections. This result agrees

2 with the significant correlation between KSHV DNA and low CD4+ cell count and seems to

3 confirm that it is the immunological deficiency (which is more pronounced in advanced HIV

4 infection) rather than the level of HIV replication that favours KSHV viraemia. The relevance

5 of the immune response to the control of KSHV replication is also demonstrated by the results

6 of a study in which KS risk was found to be associated positively with a reduced number of

7 lymphocytes, including CD4-positive cells (<457 cells/mL;) (Brown et al., 2006).

8 Almost $60 \%$ of patients with KSHV DNA-positive PBMCs also showed the presence of

9 HHV8 in plasma. Absolute CD4+ cell counts and percentages were significantly lower in

10 patients who were KSHV DNA-positive in both plasma and PBMCs compared to patients

11 positive only in PBMCs. Again, the active replication of KSHV was associated significantly

12 with a low number and low percentage of CD4+ cells, and this confirms the more relevant

13 role of immune response in controlling KSHV replication.

14 Previous studies have indicated a correlation between KSHV replication and KS pathogenesis

15 (Whitby et al., 1995; Cannon et al., 2003; Lorenzen et al, 2002; Smith et al., 1997; Broccolo 16 et al., 2002; Engels et al., 2003). In individuals infected with HIV the use of HAART has a 17 role in reducing the frequency of KSHV viraemia, mostly because of the immuno-restorative 18 properties of HIV treatment (Gill et al., 2002; Rizzieri et al., 1997; Lebbe et al., 1998). 19 Treatment with a regimen that includes a protease inhibitor was associated with the clearance 20 of KSHV DNA in KS lesions and PBMCs, and with the regression of KS lesions in AIDS 21 patients (Lebbe et al., 1998; Blum et al., 1997). Furthermore, a number of reports have linked 22 tumour regression after the initiation of HAART to the restoration of immune function 23 (Dupont et al., 2000; Marcelin et al., 2004), and it has been reported that KSHV DNA amount 24 in PBMCs rebounded in patients with KS after a short interruption of efficient antiretroviral 25 therapy (Parisi et al., 2002). 
1 Longitudinal observations on KSHV viraemia are limited. In a large cohort of homosexual

2 men who seroconverted to KSHV antigens, KSHV viraemia persisted for up to 6 months

3 (Goudsmit et al., 2000). This issue was addressed in a subgroup of patients from the cohort of

4 this study. KSHV viraemia persisted in the majority of patients who were untreated or treated

5 unsuccessfully with HAART. By contrast, all of the patients on successful HAART cleared

6 KSHV from their blood after a mean period of 17 months.

7 Before drawing any conclusions, some potential biases of the study must be addressed. The

8 cross-sectional design of the study does not allow conclusive explanation of the correlation

9 between KSHV viraemia and low CD4+ cell count. However, although the small number of

10 patients enrolled in this longitudinal study may limit its conclusiveness, the low CD4+ cell

11 counts in patients on HAART was associated significantly with active replication of KSHV.

12 Studies in a larger population are required to confirm this result. Finally, the lack of risk

13 factors for HIV infection for less than $10 \%$ of the patients may have caused misclassification,

14 potentially biasing the correlation between unprotected homosexual relationships and KSHV 15 viraemia.

16 In conclusion, KSHV DNA-positive results were observed in approximately $15 \%$ of an HIV17 positive cohort of Italian male subjects. The active replication of KSHV was associated 18 significantly with a low number of CD4+ cells, and it was more frequent in patients with 19 chronic than acute HIV infections. A longitudinal study of a limited number of patients 20 demonstrated a direct correlation between immune recovery during HAART and the 21 disappearance of KSHV DNA. 
1

2 Potential conflicts of interest: No conflicts

3 


\section{References}

2 Anderson LA, Lauria C, Romano N, Brown EE, Whitby D, Graubard BI, Li Y, Messina A, 3 Gafà L, Vitale F, Goedert JJ. 2008. : Risk factors for classical Kaposi sarcoma in a 4 population-based case- control study in Sicily. Cancer Epidemiol Biomarkers Prev. 5 Dec;17(12):3435-43.

6

7 Andreoni M, El-Sawaf G, Rezza G, Ensoli B, Nicastri E, Ventura L, Ercoli L, Sarmati L, 8 Rocchi G 1999. High seroprevalence of antibodies to human herpesvirus-8 in Egyptian 9 children: evidence of nonsexual transmission. J Natl Cancer Inst;91: 465-9.

Blum L, Pellet C, Agbalika F, Blanchard G, Morel P, Calvo F, Lebbé C. 1997,. Complete 12 remission of AIDS-related Kaposi's sarcoma associated with undetectable human herpesvirus 138 sequences during anti-HIV protease therapy. AIDS 11: 1653-1655.

Boshoff C,Weiss RA. 1998. Kaposi's sarcoma associated herpesvirus. Adv Cancer Res; $16 \quad 75: 57-86$.

17

Broccolo F, Bossolasco S, Careddu AM, Tambussi G, Lazzarin A, Cinque P. 2002. Detection of DNA of lymphotropic herpesviruses in plasma of human immunodeficiency virus-infected patients: frequency and clinical significance. Clin Diagn Lab Immunol; 9:1222-8.

Brown EE, Whitby D, Vitale F, Marshall V, Mbisa G, Gamache C, Lauria C, Alberg AJ, Serraino D, Cordiali-Fei P, Messina A, Goedert JJ. 2006. Virologic, hematologic,and immunologic risk factors for classic Kaposi sarcoma. Cancer. Nov 1;107(9):2282-90. 
1 Campbell TB, Fitzpatrick L, MaWhinney S, Zhang XQ, Schooley RT 1999. Human

2 herpesvirus 8 (Kaposi's sarcoma-associated herpesvirus) infection in men receiving treatment

3 for HIV-1 infection. J Acquir Immune Defic Syndr; 22:333-40.

4

5 Campbell TB, Staskus KA, Folkvord J, White IE, Neid J, Zhang XQ, Connick E. 2005. .:

6 Persistence of Kaposi sarcoma-associated herpesvirus (KSHV)-infected cells in KSHV/HIV-

7 1-coinfected subjects without KSHV-associated diseases. J Infect Dis.191(3):367-71.

8

9 Cannon MJ, Dollard SC, Black JB, Edlin BR, Hannah C, Hogan SE, Patel MM, Jaffe HW, 10 Offermann MK, Spira TJ, Pellett PE, Gunthel CJ. 2003. .: Risk factors for Kaposi's sarcoma 11 in men seropositive for both human herpesvirus 8 and human immunodeficiency virus. AIDS; $12 \quad 17: 215-22$.

13

14 Cattelan AM, Calabrò ML, Gasperini P, Aversa SM, Zanchetta M, Meneghetti F, De Rossi A, 15 Chieco-Bianchi L. 2001: Acquired immunodeficiency syndrome-related Kaposi's sarcoma 16 regression after highly active antiretroviral therapy: biologic correlates of clinical outcome. J 17 Natl Cancer Inst Monogr. 28:44-9

18

Chang Y, Cesarman E, Pessin MS, Lee F, Culpepper J, Knowles DM, Moore PS. 1994.Identification of Herpesvirus-like DNA sequences in AIDS-associated Kaposi's 21 sarcoma. Science $266: 1865-9$

Dupont C, Vasseur E, Beauchet A, Aegerter P, Berthé H, de Truchis P, Zucman D, Rouveix 24 E, Saiag P. 2000. Long-term efficacy on Kaposi's sarcoma of highly active antiretroviral 25 therapy in a cohort of HIV-positive patients. AIDS, 14: 987-993. 
1 Engels EA, Biggar RJ, Marshall VA, Walters MA, Gamache CJ, Whitby D, Goedert JJ. 2003.

2 Detection and quantification of Kaposi's sarcoma-associated herpesvirus to predict AIDS-

3 associated Kaposi's sarcoma. AIDS; 17:1847-51.

4

5 Gill J, Bourboulia D, Wilkinson J, Hayes P, Cope A, Marcelin AG, Calvez V, Gotch F,

6 Boshoff C, Gazzard B. 2002. .: Prospective study of the effects of antiretroviral therapy on

7 Kaposi Sarcoma-associated Herpesvirus infection in patients with and without Kaposi 8 Sarcoma. J Acquir Immune Defic Syndr 31:384-90.

9

Goudsmit J, Renwick N, Dukers NH, Coutinho RA, Heisterkamp S, Bakker M, Schulz TF, 11 Cornelissen M, Weverling GJ. 2000. .: Human herpesvirus 8 infections in the Amsterdam 12 Cohort Studies (1984-1997): analysis of seroconversions to ORF65 and ORF73. Proc Natl 13 Acad Sci U S A; 97:4838-43.

Hengge UR, Ruzicka T, Tyring SK, Stuschke M, Roggendorf M, Schwartz RA, Seeber S. 16 2002. Update on Kaposi's sarcoma and other HHV8 associated diseases. Part 1: 17 epidemiology, environmental predispositions, clinical manifestations, and therapy. Lancet 18 Infect Dis; 2, 281-292

20 Johnston C, Orem J, Okuku F, Kalinaki M, Saracino M, Katongole-Mbidde E, Sande M, 21 Ronald A, McAdam K, Huang ML, Drolette L, Selke S, Wald A, Corey L, Casper C. 2009.

22 Impact of HIV infection and Kaposi sarcoma on human herpesvirus-8 mucosal replication and 23 dissemination in Uganda. PLoS One.;4(1):e4222. Epub 2009 Jan 20.

25 Krown SE, Lee JY, Dittmer DP, AIDS Malignancy Consortium 2008. More on HIVassociated Kaposi's SarcomaNew Engl J Med; 358(5):535-6 
2 Laney AS, Dollard SC, Jaffe HW, Offermann MK, Spira TJ, Gunthel CJ, Pellett PE, Cannon

3 MJ. 2004. Repeated measures study of human herpesvirus 8 (HHV-8) DNA and antibodies in

4 men seropositive for both HHV-8 and HIV AIDS; 18:1819-1826 5

6 Lebbé C, Blum L, Pellet C, Blanchard G, Vérola O, Morel P, Danne O, Calvo F. 1998.

7 Clinical and biological impact of antiretroviral therapy with protease inhibitors on HIV8 related Kaposi's sarcoma. AIDS12: F45-F49.

9

Lin L, Lee JY, Kaplan LD, Dezube BJ, Noy A, Krown SE, Levine AM, Yu Y, Hayward GS, 11 Ambinder RF. 2009. Effects of chemotherapy in AIDS-associated non-Hodgkin's lymphoma 12 on Kaposi's sarcoma herpesvirus DNA in blood. J Clin Oncol. May 20;27(15):2496-502

14 Lorenzen T, Albrecht D, Paech V, Meyer T, Hoffmann C, Stoehr A, Degen O, Stellbrink HJ, 15 Meigel WN, Arndt R, Plettenberg A. 2002. HHV-8 DNA in blood and the development of 16 HIV-associated Kaposi's sarcoma in the era of HAART--a prospective evaluation. Eur J Med 17 Res; 7:283-6.

18

Marcelin AG, Gorin I, Morand P, Ait-Arkoub Z, Deleuze J, Morini JP, Calvez V, Dupin N. 2004. .: Quantification of Kaposi's sarcoma-associated herpesvirus in blood, oral mucosa, and 21 saliva in patients with Kaposi's sarcoma. AIDS Res Hum Retroviruses.; 20:704-8.

23 Marcelin AG, Motol J, Guihot A, Caumes E, Viard JP, Dussaix E, Cadranel J, Frances C, 24 Carcelain G, Calvez V, Dupin N. 2007.: Relationship between the quantity of Kaposi 25 Sarcoma associated Herpesvirus (KSHV) in peripheral blood and effusion fluid samples and 
2 Martinez V, Caumes E, Gambotti L, Ittah H, Morini JP, Deleuze J, Gorin I, Katlama C,

3 Bricaire F, Dupin N. 2006.: Remission from Kaposi's Sarcoma on HAART is associated with

4 suppression of HIV replication and is indipendent of protease inhibitor therapy. Br J Cancer $5 \quad 94: 1000-6$

6

7 Moore PS, Kingsley LA, Holmberg SD, Spira T, Gupta P, Hoover DR, Parry JP, Conley LJ, 8 Jaffe HW, Chang Y. 1996. Kaposi's sarcoma-associated herpesvirus infection prior to onset of 9 Kaposi's sarcoma. AIDS 10:175-80.

11 Parisi SG, Sarmati L, Pappagallo M, Mazzi R, Carolo G, Farchi F, Nicastri E, Concia E, 12 Rezza G, Andreoni M. 2002.Prevalence trend and correlates of HHV8 infection among HIV 13 infected individuals. J Acquir Immune Defic Syndr,29(3), 295-299.

Parisi SG, Sarmati L, Pappagallo M, Mazzi R, Carolo G, Farchi F, Nicastri E, Concia E, 16 Rezza G, Andreoni M. 2002. Human herpesvirus 8 cytoviraemia rebound in a patient with 17 Kaposi's sarcoma after a short interruption of efficient antiretroviral therapy. AIDS. 18 16(7):1089-91.

20 Parisi SG, Boldrin C, Cruciani M, Nicolini G, Cerbaro I, Manfrin V, Dal Bello F, Franchin E, 21 Franzetti M, Rossi MC, Cattelan AM, Romano L, Zazzi M, Andreoni M,

22 Palù G. 2007. : Both Human Immunodeficiency Virus Cellular DNA Sequencing and Plasma 23 RNA Sequencing are Useful for Detection of Drug Resistance Mutations in Blood Samples 24 from Antiretroviral Drug-Naive Patients. J Clin Microb,; 45(6):1783-1788. 
1 Plancoulaine, S., Abel, L., van Beveren, M. \& Gessain, A. 2002. High titers of anti-human

2 herpesvirus 8 antibodies in elderly males in an endemic population. J Natl Cancer Inst; 94, $3 \quad 1333-1335$.

4

5 Poole LJ, Zong JC, Ciufo DM, Alcendor DJ, Cannon JS, Ambinder R, Orenstein JM, Reitz 6 MS, Hayward GS. 1999. Comparison of genetic variability at multiple loci across the 7 genomes of the major subtypes of Kaposi’s Sarcoma-Associated Herpesvirus reveals evidence 8 for recombination and for two distinct types of open reading frame K15 alleles at the right9 hand end. Journal of Virology 73: 6646-60.

11 Rezza G, Tchangmena OB, Andreoni M, Bugarini R, Toma L, Bakary DK, Glikoutou M, 12 Sarmati L, Monini P, Pezzotti P, Ensoli B. 2000.Prevalence and risk factors for human 13 herpesvirus 8 infection in northern Cameroon. Sex Transm Dis 27:159-64.

Rizzieri DA, Liu J, Traweek ST, Miralles GD. 1997. Clearance of HHV-8 from peripheral 16 blood mononuclear cells with a protease inhibitor [letter]. Lancet; 349:775-6.

18 Schulz, T. F. \& Moore, P. S. 1999. Kaposi's sarcoma-associated herpesvirus: a new human 19 tumor virus, but how? Trends Microbiol 7, 196-200.

21 Sirianni MC, Vincenzi L, Topino S, Giovannetti A, Mazzetta F, Libi F, Scaramuzzi D, 22 Andreoni M, Pinter E, Baccarini S, Rezza G, Monini P, Ensoli B. 2002. : NK cell activity 23 controls human herpesvirus 8 latent infection and is restored upon highly active antiretroviral 24 therapy in AIDS patients with regressing Kaposi's sarcoma. Eur J Immunol. 32(10):2711-20. 
1 Smith MS, Bloomer C, Horvat R, Goldstein E, Casparian JM, Chandran B. 1997.Detection of

2 human herpesvirus 8 DNA in Kaposi's sarcoma lesions and peripheral blood of human

3 immunodeficiency virus-positive patients and correlation with serologic measurements. J

4 Infect Dis 176:84-93.

6 Taylor MM, Chohan B, Lavreys L, Hassan W, Huang ML, Corey L, Ashley Morrow R,

7 Richardson BA, Mandaliya K, Ndinya-Achola J, Bwayo J, Kreiss J. 2004.: Shedding of

8 Human Herpesvirus 8 in oral and genital secretions from HIV-1-seropositive and seronegative

9 Kenyan women. J Inf Dis, 190:484-8.

11 Varthakavi V, Smith RM, Deng H, Sun R, Spearman P. 2002. Human immunodeficiency 12 virus type-1 activates lytic cycle replication of Kaposi's sarcoma-associated herpesvirus 13 through induction of KSHV Rta. Virology 297: 270-280.

14

15 Viard JP, Burgard M, Hubert JB, Aaron L, Rabian C, Pertuiset N, Lourenço M, Rothschild C, 16 Rouzioux C. 2004. : Impact of 5 years of maximally successful highly active antiretroviral 17 therapy on CD4 cell count and HIV-1 DNA level. AIDS 18:45-49.

18

19 Whitby D, Howard MR, Tenant-Flowers M, Brink NS, Copas A, Boshoff C, Hatzioannou

20 T, Suggett FE, Aldam DM, Denton AS. 1995. :. Detection of Kaposi sarcoma associated 21 herpesvirus in peripheral blood of HIV-infected individuals and progression to Kaposi's 22 sarcoma Lancet346:799-802.

24 White I.E. and Campbell T.B. 2000. Quantitation of Cell-Free and Cell-Associated Kaposi's 25 Sarcoma-Associated Herpesvirus DNA by Real-Time PCR. Journal of Clinical Microbiology 38 (5):1992-95. 
1

2 Zeng Y, Zhang X, Huang Z, Cheng L, Yao S, Qin D, Chen X, Tang Q, Lv Z, Zhang L, Lu C.

3 2007. Intracellular Tat of human immunodeficiency virus type 1 activates lytic cycle

4 replication of Kaposi's sarcoma-associated herpesvirus: role of JAK/STAT signaling. J Virol $5 \quad 81: 2401-2417$.

6 